\title{
Prevalence and influence of tuberculosis in the neurologic manifestations of the Human T cell lymphotropic virus type 1 (HTLV-1)
}

\author{
Maria de Lourdes Bastos ${ }^{1,2,3^{*}}$, Anselmo Souza ${ }^{1}$, Natália Carvalho ${ }^{1}$, Yuri Neves ${ }^{1}$, Silvane Santos ${ }^{1,4}$, \\ Edgar M Carvalho $1,2,4$
}

From 16th International Conference on Human Retroviruses: HTLV and Related Viruses

Montreal, Canada. 26-30 June 2013

HTLV-1 infects mainly T cells, leading to activation and cellular proliferation with exaggerated production of pro-inflammatory cytokines. The majority of HTLV-1 infected patients are considered as HTLV-1 carriers, but $5 \%$ will develop HTLV-1 associated myelopathy (HAM) and about $15 \%$ overactive bladder, an oligosymptomatic form of HAM. HTLV-1 is associated with increased susceptibility to Mycobacterium tuberculosis infection but up to now it is unknown if HTLV-1 influences the severity of tuberculosis and if tuberculosis may influence the outcome of HTLV-1. The aims of this study were to determine the prevalence and severity of tuberculosis (TB) in HTLV-1 infected patients and analyze whether TB influences the outcome of HTLV-1 infection. This is a cross-sectional study, in which the prevalence of tuberculosis was analyzed in 166 HTLV-1 infected individuals. Cytokine productions were determined by ELISA, the proviral load was evaluated by PCR. Tuberculosis occurred in $33(22 \%)$ of cases and $70(42 \%)$ had a positive tuberculin skin test (TST) (latent tuberculosis). The majority of the cases did not have severe tuberculosis. There was no difference in the proviral load, but there was a higher frequency of HAM/TSP in the group with tuberculosis than in HTLV-1 infected subjects without TB $(\mathrm{P}<0.05)$. This study shows that the prevalence of M.tuberculosis infection is 6 fold higher in HTLV-1 infected individuals than that described in the Brazilian population the majority of co-infected had latent tuberculosis and HTLV-1 may influence progression from infection to HAM/TSP.

${ }^{1}$ Serviço de Imunologia, Complexo Hospitalar Universitário Professor Edgard Santos, Universidade Federal da Bahia, Salvador-BA, Brazil

Full list of author information is available at the end of the article

\section{Funded by}

National Institute of Health (NIH AI 079238) and CNPq.

\section{Authors' details}

'Serviço de Imunologia, Complexo Hospitalar Universitário Professor Edgard Santos, Universidade Federal da Bahia, Salvador-BA, Brazil. Escola Bahiana de Medicina e Saúde Pública, Salvador-BA, Brazil. ${ }^{3}$ Hospital Especializado Octávio Mangabeira, Salvador-BA, Brazil. ${ }^{4}$ Instituto Nacional de Ciência e Tecnologia de Doenças Tropicais (INCT-DT), Brazil.

Published: 7 January 2014

\section{doi:10.1186/1742-4690-11-S1-P6}

Cite this article as: de Lourdes Bastos et al.: Prevalence and influence of tuberculosis in the neurologic manifestations of the Human T cell lymphotropic virus type 1 (HTLV-1). Retrovirology 2014 11(Suppl 1):P6.
Submit your next manuscript to BioMed Central and take full advantage of:

- Convenient online submission

- Thorough peer review

- No space constraints or color figure charges

- Immediate publication on acceptance

- Inclusion in PubMed, CAS, Scopus and Google Scholar

- Research which is freely available for redistribution
() Biomed Central 